\title{
An Investigation of Use of Information and Communication Technology on Creativity of Perspective Teachers and Students of Technical Education
}

\author{
Anu Malhotra ${ }^{1, P h . D}$ Veena Bana ${ }^{2, P h . D}$ Rahul Malhotra ${ }^{3, P h . D}$ \\ Punjabi University, Patiala, Maharaja Ganga Singh University, Bikaner, Punjab Technical University, Jalandhar
}

\begin{abstract}
We are living in an age, where creativity, achievement, knowledge and innovation are powering the world at an ever increasing pace. The genes of this revolution are information and communication technologies. Information and communication technologies (ICT) are increasingly being used to deliver on promises of universal education. It is an important tool for delivering education around the world. Creativity is a talent, or as a characteristic of an eminent people. Creativity is not only an innate ability, but due to the habitual nature of it as a response of any given situation, it is a lifestyle, or an attitude towards life. To analyze the comparative effect of information and communication technology (ICT) on creativity questionnaire technique was adopted as the data collection instrument. The predictive variable for this study is Creativity, which is dependent on Criterion- Fluency, Flexibility and Originality. The research was conducted on perspective teachers and Students of technical Education. $46.965,45.508$ and 20.10,chi square values of Fluency, Flexibility and Originality, indicates the positive impact of use of information and communication technology on Creativity of human.
\end{abstract}

Keywords:

Creativity, ICT, Education Technology, Fluency, Flexibility, Originality

\section{INTRODUCTION}

Education lays the foundation for the fulfillment of a person's dreams and aspirations. It is the process of gaining knowledge, inculcating forms of proper conduct and acquiring technical competency. 'Cultivate' and 'civilize' are synonyms to the word 'educate'. Education is important as it teaches us the right behavior, the good manners, that make us civilized. It includes cultivation of an innocent mind, development of skills along with the achievement of one's physical, mental and social terms. The process of education consists of defined phases starting from formal education and it continues throughout the life. The purpose of education is to bring about profoundness to one's emotions, to broaden one's perspectives, and to lead a healthier approach of looking at life.

Education may be the most successful institution to emerge from the industrial age. Twentieth century nations have thrived because they identified and employed effective strategies for education and employment of the general population. The world is changing. Technology makes us smarter. In today's classroom, technology is not only a tool, but also a resource for accessing information. Everyday, new ways have been used to integrate technology into learning process.

Educational technology, especially computers and computer peripherals, have grown tremendously and have permeated all areas of student's life. According to Lever-Duffy J., McDonald J. B. and Mizell A. P. (2005) "education technology might include media, models, projected and non-projected visuals, as well as audio, video and digital media".

Educational technology is an array of tools that might prove helpful in advancing student learning. Computer and web technology have revolutionized the field of education. The computers provide an interactive audio-visual media through PowerPoint presentations and animation software's. The visual effects provided by animation and presentation software, enhances the interest of the students. On the other hand, web is a huge information base. Internet is revolutionizing education. The internet, a global network connecting millions of computers and computer users, is a new resource of educators. Globalization is a worldwide

phenomena by which the world comes together to share the information together. In educational globalization, internet provides upto date information of a variety of classroom related topics unavailable from other sources.

Technology brought a huge change in communication. Communication system has evolved from pigeons carrying messages across countries, right upto e-mails and instant messages that travel long distances in seconds. Communication plays an important role in education by transmission of knowledge and information. The availability of media, compact discs (CD's), films, charts, slides, models has supplemented to books and teachers in terms of transmitting knowledge. Communication has played an important role in educational environment, distance education, broadcasting of lecture by television media, EDUSAT and NPTEL etc. This paper is a short component of a broad research on the use of Information and Communication Technology on Creativity, which is divided into VIII Sections. Section I gives the introduction about Creativity and Technology, which is followed by characteristics of creative personality, Types and Determinants of Creativity in Section II and III. Section IV elaborates the brief methodology which is followed by the 
analysis of creativity on Perspective Teaches and students of technical education of Punjab State in section V. Section VI

\section{CREATIVITY}

Creativity can be developed through education. It is possible in any activity that engages intelligence. Information and communication technology and digital technologies have enormous potential for enabling creativity by providing tools, processes and audiences of all ages and abilities and across the curriculum. Creativity is one of the most complicated concepts in psychology. Definitions of creativity differ, but they have in common their emphasis on people's ability to produce products that are not only high but also novel. Boden M.A. (2001) believes creativity is the ability to come up with new ideas that are surprising yet intelligible, and also valuable in some way. Five characteristics of creativity were expressed by Denning T. (2003) includes imagination, a fashioning process, pursuing purpose, being original and judging value. Resnick M. (2007) said " Success in the future- for individuals, for communities, for companies, for nation as a whole- will be based not on what we know or how much we know, but on our ability to think and act creatively".

Cordes et.al (2000) argue that instead of being creative and using information and communication technologies to enhance learning opportunities in the classroom, it has been common to see students involved with mindless and passive interactions. It is responsibility of education, parents to encourage youth to be selective and creative in the way they deal with the mountains of data that are at their finger tips. Guidance, education and promotion of positive aspects of information and communication technologies is required to encourage the youth.

\section{CREATIVITY TECHNOLOGY}

AND

We live in technological world where information and communication technologies are fundamental to most activities. Information and communication technology is used to access, manage and evaluate information, develop new understandings, and communicate with others in order to participate effectively in society. Information and communication technologies enable students to efficiently and effectively access digital information, solving problem and decision making, producing creative solutions to support learning and develop new areas of learning. Information and communication technologies help to communicate, share and work in local and global environments.

The lexeme in the English word creativity comes from latent term "Creo" to create, make and its derivational suffixes comes from Latin. The word "create" appears in English as early as the 14th century notably in Pason's tale. Creativity is often conceived to be the ability to bring something new in existence; it is not a fixed and static quality but something that changes overtime.

An individual can be extremely bright being creative or highly creative but not necessarily intellectually gifted (Rajput J.S. 2000). It is the quality of thought to be composed of broad continuous upon which all members of population may be placed in different degree. It is the capacity of constructive and manipulating the new objects. describes the tentativity of Hypothesis and the results and conclusions are discussed in Section Vii and VIII. Creativity is fostered by self confidence, intellectual curiosity. Therefore the teacher should try to build up the confidence among the students and the required freedom is given to students to work, play and study.

Guilford J.P. (1959) elaborates creativity is the ability to go beyond the immediate solution, ability to redefine the problem or some part of it. It is an ability to cope with ideas that are unusual and it's an ability to change the approach of the problem. Creativity is an ability to create or the ability to produce something new through imaginative skill. Creativity is not only an innate ability or skill, but due to the habitual nature of it as a response to any given situation, it is a life style, or an attitude towards life.

Guilford J.P. (1959) used a factor analytic technique to separate creative thinking skills from others. He identified two distinct forms of thinking, that is, divergent thinking and convergent thinking. Divergent thinking belongs to creative thoughts or it is the ability to access memory to derive unique, multiple, and numerous answers to open ended questions. On the other hand convergent thinking means coming up with one right answer for each question. It is commonly associated with Intelligent Quotient tests. Following are characteristics of creative personality Csikszentmihalyi M. (1997):

- Creative individuals have a great deal of energy, but they are also often quiet and at rest.

- Creative individuals tend to be smart, yet also naive at the same time.

- Creative individuals have a combination of playfulness and discipline, or responsibility and irresponsibility.

- Creative individuals alternate between imagination and fantasy ant one end, and rooted sense of reality at the other.

- Creative people seem to harbor opposite tendencies on the continuum between extroversion and introversion.

- Creative individuals are also remarkable humble and proud at the same time.

- Creative individuals to a certain extent escape rigid gender role stereotyping and have a tendency toward androgyny.

- Generally, creative people are thought to be rebellious and independent.

- Most creative persons are very passionate about their work, yet they can be extremely objective about it as well.

- The openness and sensitivity of creative individuals often exposes them to suffering pain yet also a great deal of enjoyment.

The following are some Affective/Emotional-Social Creative Individuals described by Clark B. (1994):

- $\quad$ A special kind of perception

- More spontaneous and expressive

- Unfrightened by the unknown, the mysterious, the puzzling; often attracted to it

- Resolution of dichotomies: selfish and unselfish; duty and pleasure; work and play; strong ego and egolessness

- $\quad$ Able to integrate 
- More self-accepting; lack fear of own emotions, impulses, and thoughts

- Have more of themselves available for use, for enjoyment, for creative purposes; waste less of their time and energy protecting themselves

- Involved in more peak experiences, integration within the person and between the person and the world, and transcendence

- $\quad$ Capacity to be puzzled

- $\quad$ Ability to concentrate

- Ability to experience self as creative, as the originator of one's acts

- Willingness to be born every day

- Ability to accept conflict and tension rather than avoiding them

- Courage to let go of certainties, to be different, to be concerned with truth, to be certain of one's own feelings and thoughts and trust them

- Identify closely with the feelings and expectations of others

- $\quad$ Less repressed and defensive

- More curious

- More maturely autonomous and less dependent on views of others

\section{Types of Creativity}

Creativity can be classified into three classes:

- Chance creativity: The type of creative art or act that happens by pure luck and can rarely be duplicated.

- $\quad$ Spontaneous creativity - Spontaneous creativity means bringing something new into being from a feeling of spontaneity which is designed to meet an immediate purpose.

- Conservable Creativity - Conservable creativity refers to the process "where the things created does not necessarily meet an immediate purpose'. There is very little, if any feedback is present in this type of creativity. It comes through generations to generation.

\section{Determinants of Creativity}

According to some scholars following are determinants of creativity:

- The values and practice of the culture in which a person is brought up and lives

- A person's biological constitution

- Nature of the organization or institutions

- Genetic Inheritance

- The orientation of the group

- The nature of the work the person does

According to Franken R E. (1994), there are three reasons by which people are motivated to be creative:

- Need for novel varied and complex simulation

- $\quad$ Need to communicate ideas and values

- $\quad$ Need to solve problems

Creativity is not a static quality, and can be fostered by enhancing some skills. Following are some factors which fosters creativity of an individual Beckhaus S. (2009):
- Knowledge (of the field, theories and practical experience),

- Inspiration (from creative projects in the field, from other fields, interdisciplinary),

- Project management skills,

- Knowledge of creativity methods,

- Self-confidence (in their creativity and relevance of their work),

- Motivation,

- Focus (on goal and results).

Researchers enlist many possible uses for a common object, such as a cup, a paper clip, or a newspaper. Scoring is comprised of three components namely originality, fluency and flexibility. Originality is based on each response compared to total number of responses from a specific group of test takers. This is statistical variety of responses. Fluency is a total number of interpretable, meaningful and relevant ideas granted in response to stimulus. Fluency supports relevant answers.

Flexibility is based upon the total number of categories of relevant responses. The goal of the creativity test is to:

- Understand the human mind, its functioning and development.

- Discover the effective bases for individualizing instruction and to provide clues for remedial and psychotherapeutic programs.

- Evaluate the effects of educational programs, materials, curricula and teaching procedures.

In this research work creativity capacity training using model based information and communication based learning technique is used for controlled group perspective teachers and students of technical education. The perspective teachers and students of technical education under uncontrolled group were trained using traditional teaching methodologies. The divergent thinking components of creativity viz. originality, fluency and flexibility were analyzed for both the groups.

\section{BRIEF METHODOLOGY OF STUDY}

The study analyzes the comparative impact of use of information and communication technologies (ICT) on creativity of students of technical education and perspective teachers. The sampled technological and educational institutions were divided into controlled and uncontrolled groups. The survey method was method to analyze the impact of this research study. The controlled group was administered by the model based and learning based information and communication technology (ICT) techniques. Model based ICT was used by demonstrating the students by video clippings and animations for the analysis of creativity. The validity and reliability of questionnaire was examined by experts. The relevant data from the perspective teachers and students of technical education was collected and statistically analyzed through Chi-Square Test simulated in Statistical Package for the Social Sciences (SPSS) software. 


\section{ANALYSIS OF CREATIVITY}

The following sections provide discussion on number of key questions presented to the perspective teachers and students of technical education of various institutions of Punjab, Haryana and Rajasthan states of India. This discussion summarizes the effect of the use of information and communication technology (ICT) as an educational tool on their creativity and achievement ability. This chapter incorporates the discussion on various hypotheses undertaken for the analysis of creativity and analysis of achievement ability of perspective teachers and students of technical education with and without use of information and communication technology (ICT) as an educational tool.
Chi-Square analysis were used to perform the statistical Analysis using SPSS 16.0 Software.

The following sections describe the effect of use of information and communication technology on the creativity of students of technical education and perspective teachers.

\section{CREATIVITY ANALYSIS OF PERSPECTIVE TEACHERS AND STUDENTS OF TECHNICAL EDUCATION OF PUNJAB}

FLUENCY: The analysis of fluency of the perspective teachers and students of technical education of Punjab shows that the $38 \%$ of the respondents of controlled group $(n=502)$ come under the category of high achievers (HA), whereas only $14 \%$ of the respondents of uncontrolled group $(n=96)$ come under the category of high achievers (HA).

Table 1 Chi-Square Cross tabulation of Fluency of perspective teachers and students of technical education of Punjab

\begin{tabular}{|c|c|c|c|c|c|}
\hline \multirow{2}{*}{\multicolumn{2}{|c|}{$\begin{array}{l}\text { C: Controlled Group } \\
\text { U: Uncontrolled Group }\end{array}$}} & \multicolumn{3}{|c|}{ ACHIEVEMENT } & \multirow[b]{2}{*}{ Total } \\
\hline & & 1_HIGH & 2_MEDIUM & 3_LOW & \\
\hline \multirow[t]{2}{*}{$\mathbf{C}$} & Count & 192 & 231 & 79 & 502 \\
\hline & Expected Count & 172.9 & 226.7 & 102.4 & 502.0 \\
\hline \multirow[t]{2}{*}{$\mathbf{U}$} & Count & 14 & 39 & 43 & 96 \\
\hline & Expected Count & 33.1 & 43.3 & 19.6 & 96.0 \\
\hline \multirow[t]{2}{*}{ Total } & Count & 206 & 270 & 122 & 598 \\
\hline & Expected Count & 206.0 & 270.0 & 122.0 & 598.0 \\
\hline
\end{tabular}

The $46 \%$ of the respondents of controlled group come under the category of medium achievers (MA), and $40 \%$ of the respondents of uncontrolled group come under the category of medium achievers (MA). Only $15 \%$ of the respondents of controlled group come under the category of low achievers (LA), whereas $44 \%$ of the respondents of uncontrolled group come under the category of low achievers (LA). It is inferred from the computed results that the use of information and communication technologies (ICT) plays a key role in improving the Fluency of the perspective teachers and students of technical education of Punjab State. The calculated values of Chi-Square analysis (Chi-
Square $=44$, Table Value $=5$ and $\mathrm{df}=2$ ) has demonstrated that the use of information and communication technologies (ICT) has a significant effect on Fluency of the perspective teachers and students of technical education of Punjab State. Table 1 shows the Chi-Square cross tabulation of fluency of the perspective teachers and students of technical education of Punjab State. Table 2 shows the results of Chi square analysis analyzed through SPSS 16.0. Figure 1 shows the bar chart indicating the response of High, Medium and Low achievement groups in fluency of the perspective teachers and students of technical education for uncontrolled and controlled group of Punjab state.

Table 2 Chi-Square Analysis of Fluency of perspective teachers and students of technical education of Punjab

\begin{tabular}{|c|c|c|c|}
\hline & Value & Df & Asymp. Sig. (2-sided) \\
\hline Pearson Chi-Square & $46.965^{\text {a }}$ & 2 & .000 \\
Likelihood Ratio & 43.254 & 2 & .000 \\
N of Valid Cases & 598 & & \\
\hline
\end{tabular}

a. 0 cells $(.0 \%)$ have expected count less than 5 . The minimum expected count is 19.59 .

Figure 1 shows the graphical response of information and communication technology on Fluency of perspective teachers and students of technical education of Punjab for controlled and uncontrolled group comprising of 502 and 96 students respectively. 


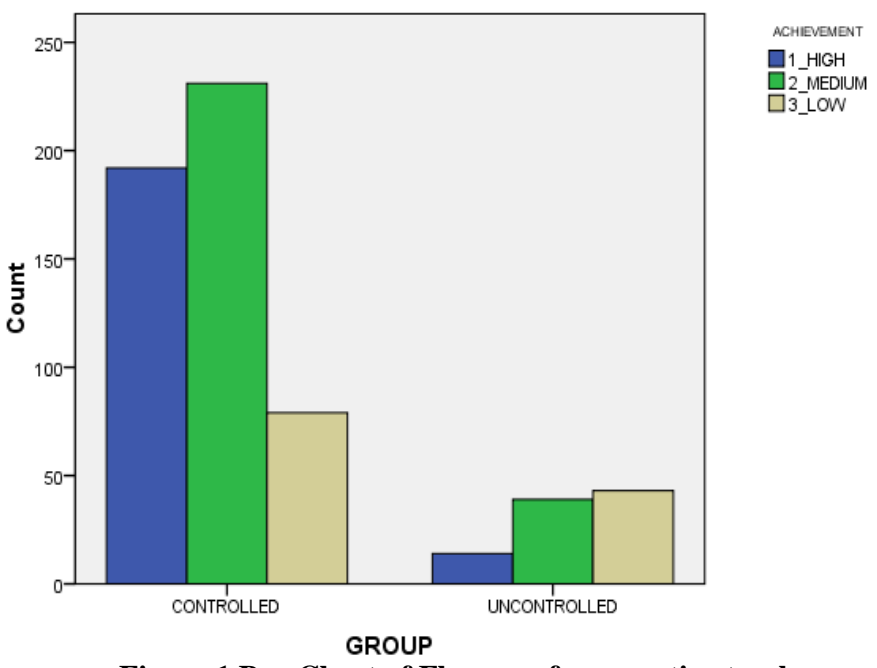

Figure 1 Bar Chart of Fluency of perspective teachers and students of technical education of Punjab

It is inferred from the bar chart that 192 students came under the category of high achievers (HA), 231 students came under the category of medium achievers (MA) and 79 students came under the category of low achievers (LA) out of 502 students of controlled group comprising of perspective teachers and students of technical education of

\section{FLEXIBILITY}

The analysis of flexibility of the perspective teachers and students of technical education of Punjab shows that the $39 \%$ of the respondents of controlled group $(n=502)$ come under the category of high achievers (HA), whereas only $19 \%$ of the respondents of uncontrolled group $(n=96)$ come under the category of high achievers (HA). The $41 \%$ of the respondents of controlled group come under the category of medium achievers (MA), and 29\% of the respondents of uncontrolled group come under the category of medium achievers (MA). Only $19 \%$ of the respondents of controlled group come under the category of low achievers (LA), whereas $51 \%$ of the respondents of uncontrolled group come under the category of low achievers (LA). It is inferred from the computed results that the use of information and communication technologies (ICT) plays a key role in improving the Flexibility of the perspective teachers and students of technical education of Punjab State. The calculated values of Chi-Square analysis (Chi-
Punjab. On the divergent side, 14 students came under the category of high achievers (HA), 39 students came under the category of medium achievers (MA) and 43 students came under the category of low achievers (LA) out of 96 students of uncontrolled group comprising of perspective teachers and students of technical education of Punjab. Square $=45$, Table Value $=5$ and $d f=2$ ) has demonstrated that the use of information and

Communication technologies (ICT) have a significant effect on Flexibility of the perspective teachers and students of technical education of Punjab State. Table 3 shows the cross tabulation of flexibility of the perspective teachers and students of technical education of Punjab State. Table 4 shows the results of Chi square analysis analyzed through SPSS 16.0. Figure 4.2 shows the bar chart indicating the response of High, Medium and Low achievement groups in flexibility of the perspective teachers and students of technical education for uncontrolled and controlled group of Punjab state

Figure 2 shows the graphical response of information and communication technology on Flexibility of perspective teachers and students of technical education of Punjab for controlled and uncontrolled group comprising of 502 and 96 students respectively.

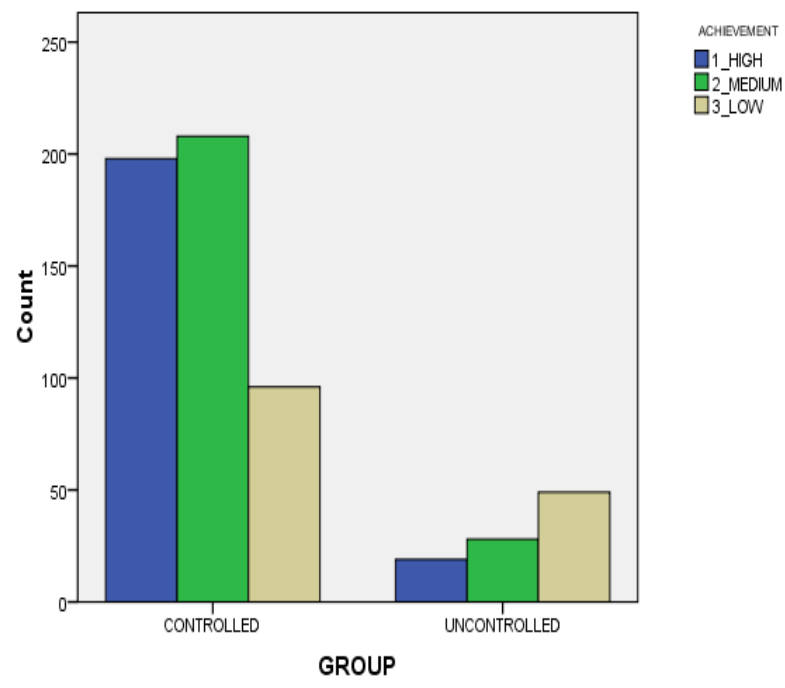

Figure 2 Bar Chart of flexibility of perspective teachers and students of technical education of Punjab 
It is inferred from the bar chart that 198 students came under the category of high achievers (HA), 208 students came under the category of medium achievers (MA) and 96 students came under the category of low achievers (LA) out under the category of medium achievers (MA) and 49 students came under the category of low achievers (LA) out of 96 students of uncontrolled group comprising of perspective teachers and students of technical education of Punjab.

\section{ORIGINALITY}

The analysis of Originality of the perspective teachers and students of technical education of Punjab shows that the $25 \%$ of the respondents of controlled group $(n=502)$ come under the category of high achievers (HA), whereas only $15 \%$ of the respondents of uncontrolled group $(n=96)$ come under the category of high achievers (HA). The $42 \%$ of the respondents of controlled group come under the category of medium achievers (MA), and $28 \%$ of the respondents of of 502 students of controlled group comprising of perspective teachers and students of technical education of Punjab. On the divergent side, 19 students came under the category of high achievers (HA), 28 students came uncontrolled group come under the category of medium achievers (MA). Only $32 \%$ of the respondents of controlled group come under the category of low achievers (LA), whereas $56 \%$ of the respondents of uncontrolled group come under the category of low achievers (LA). It is inferred from the computed results that the use of information and communication technologies (ICT) plays a key role in improving the Originality of the perspective teachers and students of technical education of Punjab State. The calculated values of Chi-Square analysis (ChiSquare $=20$, Table Value $=5$ and $\mathrm{df}=2$ ) has demonstrated that the use of information and communication technologies (ICT) has a significant effect on Originality of the perspective teachers and students of technical education of Punjab

State.

Table 5 Chi-Square Cross tabulation of Originality of the perspective teachers and students of technical education of Punjab

\begin{tabular}{|cl|c|c|c|c|}
\hline \multirow{2}{*}{$\begin{array}{l}\text { C: Controlled Group } \\
\text { U: Uncontrolled Group }\end{array}$} & \multicolumn{3}{|c|}{ ACHIEVEMENT } & \multicolumn{2}{c|}{ Total } \\
\cline { 2 - 6 } & 1_HIGH & 2_MEDIUM & 3_LOW & 502 \\
\hline C & Count & 126 & 214 & 162 & 502.0 \\
& Expected Count & 118.4 & 202.3 & 181.3 & 96 \\
& Count & 15 & 27 & 54 & 96.0 \\
\hline \multirow{2}{*}{ Total } & Expected Count & 22.6 & 38.7 & 34.7 & 598 \\
& Count & 141 & 241 & 216 & 598.0 \\
\hline
\end{tabular}

Table 5 shows the cross tabulation of Originality of the perspective teachers and students of technical education of Punjab State. Table 6 shows the results of Chi square analysis analyzed through SPSS 16.0. Figure 3 shows the bar chart indicating the response of High, Medium and Low achievement groups in Originality of the perspective teachers and students of technical education for uncontrolled and controlled group of Punjab state.

Table 6 Chi-Square Analysis of Originality of the perspective teachers and students of technical education of Punjab

\begin{tabular}{|l|l|l|c|}
\hline & Value & df & Asymp. Sig. (2-sided) \\
\hline Pearson Chi-Square & $20.104^{\mathrm{a}}$ & 2 & .000 \\
Likelihood Ratio & 19.351 & 2 & .000 \\
N of Valid Cases & 598 & & \\
\hline
\end{tabular}

a. 0 cells $(.0 \%)$ have expected count less than 5 . The minimum expected count is 22.64 .

teachers and students of technical education of Punjab for controlled and uncontrolled group comprising of 502 and 96

Figure 3 shows the graphical response of information and communication technology on Originality of perspective students respectively. 


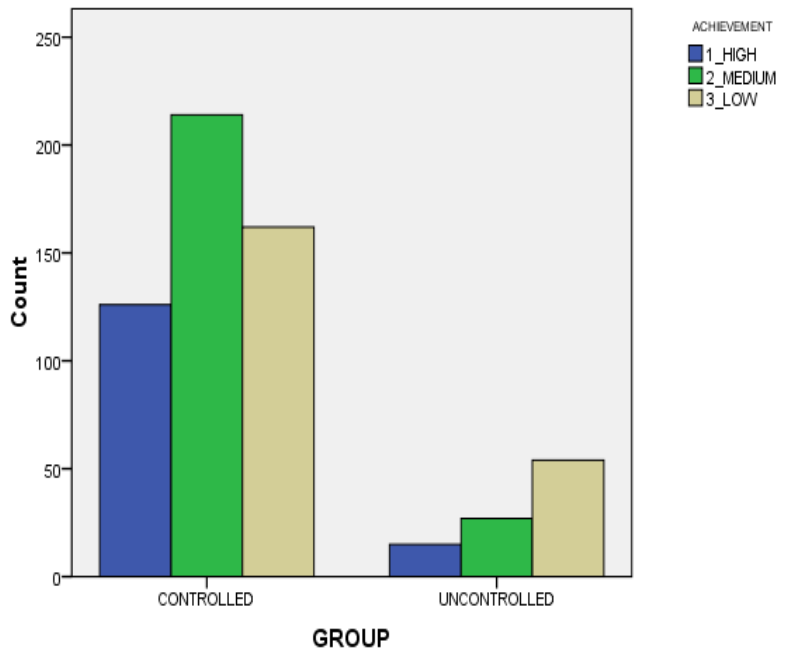

Figure 3 Bar Chart of Originality of the perspective teachers and students of technical education of Punjab It is inferred from the bar chart that 126 students came under the category of high achievers (HA), 214 students came under the category of medium achievers (MA) and 162 students came under the category of low achievers (LA) out of 502 students of controlled group comprising of perspective teachers and students of technical education of Punjab. On the divergent side, 15 students came under the category of high achievers (HA), 27 students came under the category of medium achievers (MA) and 54 students came under the category of low achievers (LA) out of 96

students of uncontrolled group comprising of perspective teachers and students of technical education of Punjab.

Creativity: The analysis of Creativity of the perspective teachers and students of technical education of Punjab shows that the $29 \%$ of the respondents of controlled group $(n=502)$ come under the category of high achievers (HA), whereas only $10 \%$ of the respondents of uncontrolled group $(n=96)$ come under the category of high achievers (HA).

Table 7 Chi-Square Cross tabulation of Creativity of the perspective teachers and students of technical education of Punjab

\begin{tabular}{|c|c|c|c|c|c|}
\hline \multirow{2}{*}{\multicolumn{2}{|c|}{$\begin{array}{l}\text { C: Controlled Group } \\
\text { U: Uncontrolled Group }\end{array}$}} & \multicolumn{3}{|c|}{ ACHIEVEMENT } & \multirow[b]{2}{*}{ Total } \\
\hline & & 1_HIGH & 2_MEDIUM & 3_LOW & \\
\hline \multirow[t]{2}{*}{$\mathbf{C}$} & Count & 147 & 262 & 93 & 502 \\
\hline & Expected Count & 131.8 & 249.3 & 120.9 & 502.0 \\
\hline \multirow[t]{2}{*}{$\mathbf{U}$} & Count & 10 & 35 & 51 & 96 \\
\hline & Expected Count & 25.2 & 47.7 & 23.1 & 96.0 \\
\hline \multirow[t]{2}{*}{ Total } & Count & 157 & 297 & 144 & 598 \\
\hline & Expected Count & 157.0 & 297.0 & 144.0 & 598.0 \\
\hline
\end{tabular}

The $52 \%$ of the respondents of controlled group come under the category of medium achievers (MA), and 36\% of the respondents of uncontrolled group come under the category of medium achievers (MA). Only $18 \%$ of the respondents of controlled group come under the category of low achievers (LA), whereas $53 \%$ of the respondents of uncontrolled group come under the category of low achievers (LA). It is inferred from the computed results that the use of information and communication technologies (ICT) plays a key role in improving the Creativity of the perspective teachers and students of technical education of Punjab State. The calculated values of Chi-Square analysis (Chi-Square $=55$, Table Value $=5$ and $\mathrm{df}=2$ ) has demonstrated that the use of information and communication technologies (ICT) has a significant effect on Creativity of the perspective teachers and students of technical education of Punjab State. Table 7 shows the cross tabulation of Creativity of the perspective teachers and students of technical education of Punjab State. Table 8 shows the results of Chi square analysis analyzed through SPSS 16.0. Figure 4 shows the bar chart indicating the response of High, Medium and Low achievement groups in Creativity of the perspective teachers and students of technical education for uncontrolled and controlled group of Punjab state. 
Table 8 Chi-Square Analysis of Creativity of the perspective teachers and students of technical education of Punjab

\begin{tabular}{|l|l|l|c|}
\hline & Value & df & Asymp. Sig. (2-sided) \\
\hline Pearson Chi-Square & $55.005^{\mathrm{a}}$ & 2 & .000 \\
Likelihood Ratio & 49.896 & 2 & .000 \\
$\mathrm{~N}$ of Valid Cases & 598 & & \\
\hline
\end{tabular}

a. 0 cells $(.0 \%)$ have expected count less than 5 . The minimum expected count is 23.12 .

Figure 4 shows the graphical response of information and controlled and uncontrolled group comprising of 502 and 96 communication technology on Creativity of perspective students respectively teachers and students of technical education of Punjab for
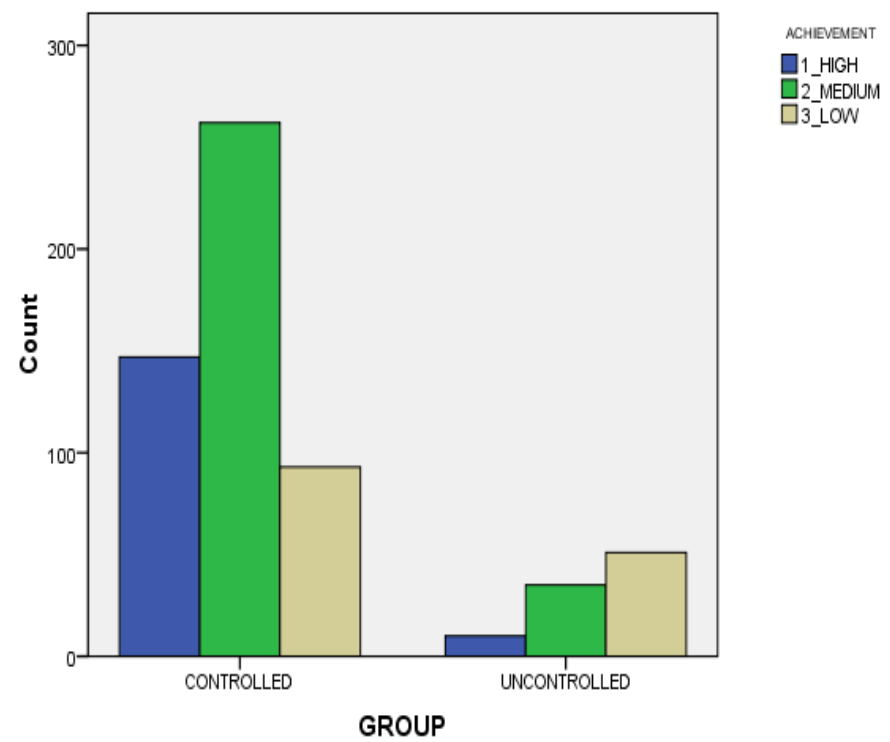

Figure 4 Bar Chart of Creativity of the perspective teachers and students of technical education of Punjab

It is inferred from the bar chart that 147 students came under the category of high achievers (HA), 262 students came under the category of medium achievers (MA) and 93 students came under the category of low achievers (LA) out of 502 students of controlled group comprising of perspective teachers and students of technical education of lled group comprising of perspective teachers and students of technical education of Punjab.

\section{HYPOTHESIS OF THE STUDY}

This research study provides sufficient evidence to reject null hypothesis.

Hypothesis: There is no significant effect of ICT on creativity level of perspective teachers and students of technical education.

The chi-square results for the analysis of creativity with the use of ICT on perspective teachers and students of technical education shows the following results.

The chi-square values for the analysis of fluency, flexibility and originality of the perspective teachers and students of technical education of Punjab are 46.965, 45.508 and 20.10 respectively as tabulated in Tables 2, 4 and 6. Analysis of Creativity of the perspective teachers and students of technical education of Punjab is 55 as tabulated in Table 8.
Punjab. On the divergent side, 10 students came under the category of high achievers (HA), 35 students came under the category of medium achievers (MA) and 51 students came under the category of low achievers (LA) out of 96 students

of

uncontro

\section{RESULTS}

This research work analyzes the impact of use of Information and communication technologies on creativity in Punjab with a sample size of 598. The sampling technique was used to select the samples from the population. The chi-square test was employed to statistically analyze the creativity of perspective teachers and students of technical education. Model based and learner based ICT techniques were used to teach the controlled group, whereas conventional teaching methodology was adopted for uncontrolled group.

The chi-square analysis was performed to analyze the impact of use of ICT on creativity viz. fluency, flexibility and originality. It is evident from the chi-square statistics that the information and communication technology has a significant role in the improvement of creativity and achievement ability of the perspective teachers and students of technical education. 


\section{CONCLUSIONS}

This survey based research work lays emphasis on the use of information and communication technology (ICT) tools for the purpose of education. Perspective teachers and students of technical education participated in this survey. Model based and learner based information and communication technology (ICT) methods have been used in this research work. It is evident from the analysis and

Wrapping up, the results from the research work it is concluded that the information and communication technologies (ICT) and its tools are the integral part of interpretations of data and the results obtained from ChiSquare analysis that information and communication technology (ICT) plays an inevitable role in the process of education. Variable Creativity has further dependent variables, viz. Fluency, Flexibility, and Originality.

In conclusion, it is emphasized that information and communication technologies (ICT) has shown a great impact in enhancing the Creativity of perspective teachers and students of technical education. education for better perceptive of the prospectus and for the educational growth of the Nation 


\section{REFERENCES}

1. Boden M.A. (2001), "Creativity and Knowledge", Craft A., Jeffrey B., Leibling M., A Book on Creativity in Education, London: Continuum.

2. Bingimlas K.A. (2009), "Barriers to the Successful Integration of ICT in Teaching and Learning Environments", Eurasia Journal of Mathematics, Science and Technology Education, 5(3), pp.235-245.

3. Beckhaus S., (2009), "Creativity and HCI: From Experience to Design in Education", IFIP - International Federation for Information Processing, Vol. 289, 2009, pp 1-11.

4. Bosch A. (2009), "Introducing Learning Technologies into Egyptian Schools: Where There is Demand There is a Way", Journal of Education for International Development, (2), pp.13-20.

5. Clark B. (1994), "A product development challenge”, A Harvard Business Review Book.

6. Csikszentmihalyi M. (1997), "Handbook of positive psychology”, Oxford University Press.

7. Cordes C., Miller E. (2000), "Fool's gold: A critical look at computers in childhood", http://drupal6.allianceforchildhood.org/fools_gold

8. Denning T., Fisher T., Higgins C., Loveless A., Tweats R. (2003), "Thinking Skills and ICT Use in the Classroom?", In the Proceedings of the Conference on ICT and the Teacher of the Future, Melbourne, Australia, 23, pp.31-33.

9. Franken R.E. (1994), "Human Motivation”, Brooks/Cole Publishing Company.

10. Guilford J.P (1967), "The Nature of Human Intelligence”, McGraw Hill, New York.

11. Hakan T., Meryem Y.S., Turkan K., Yavuz I., Gonca K. (2009), "The Effects of Computer Games on Primary School Students' Achievement and Motivation in Geography Learning", Elsevier Journal of Computers and Education, 52(1), January 2009, pp. 68-77.

12. Ho J., Thukral H. (2009), "Tuned into Student Success Assessing the Impact of Interactive Radio Instruction for the Hardest-to-Reach,” Journal of Education for International Development, 4(2), pp.34-51.

13. Lever-Duffy J., McDonald J. B., Mizell A. P. (2005), "Teaching and learning with technology", Pearson Publishers, San Francisco 


\begin{abstract}
About the Authors:-
Dr.Anu Malhotra-Born on $13^{\text {th }}$ day of April 1977 at Ferozepur. She obtained Masters of English Degree from Punjabi University Patiala, Bachelor of Education Degree from Punjab University Chandigarh and Masters of Education Degree from Punjabi University Patiala. She has conducted research on Information and Communication Technology and obtained Degree of Philosophy in the Faculty of Education from Maharaja Ganga Singh University, Bikaner. She has vast teaching experience in teaching English and Communication Skills. Her research area includes Information and Communication Technology, Educational Technology.

Dr. Veena Bana-An Eminent Educationalist, Member of Board of studies of various Universities, an Expert constituted by National Council of Educational Research and Training is a senior faculty in Centre of Teacher Education in Gram Utahan Vidhyapeeth ,Sangaria under Maharaja Ganga Singh University, Bikaner.

Dr.Rahul Malhotra- A well known Educationalist and Researcher in the field of Technical Education, guided about 45 Masters thesis and ongoing Doctoral level of research thesis, is working as a Director-Principal in Adesh Institute of Technology, Chandigarh.
\end{abstract}

